University of Nebraska - Lincoln

DigitalCommons@University of Nebraska - Lincoln

Faculty Publications from the Harold W. Manter Laboratory of Parasitology

2007

\title{
A New Species of Subulura (Nematoda: Subuluroidea) from Ground Squirrels, Spermophilus spilosoma Bennett, 1833, in New Mexico
}

John E. Ubelaker

Southern Methodist University, ubelaker@smu.edu

Roxanne Easter-Taylor

Southern Methodist University

April Marshall

Southern Methodist University

Donald W. Duszynski

University of New Mexico, eimeria@unm.edu

Follow this and additional works at: https://digitalcommons.unl.edu/parasitologyfacpubs

Part of the Parasitology Commons

Ubelaker, John E.; Easter-Taylor, Roxanne; Marshall, April; and Duszynski, Donald W., "A New Species of Subulura (Nematoda: Subuluroidea) from Ground Squirrels, Spermophilus spilosoma Bennett, 1833, in New Mexico" (2007). Faculty Publications from the Harold W. Manter Laboratory of Parasitology. 138. https://digitalcommons.unl.edu/parasitologyfacpubs/138

This Article is brought to you for free and open access by the Parasitology, Harold W. Manter Laboratory of at DigitalCommons@University of Nebraska - Lincoln. It has been accepted for inclusion in Faculty Publications from the Harold W. Manter Laboratory of Parasitology by an authorized administrator of DigitalCommons@University of Nebraska - Lincoln. 


\title{
A NEW SPECIES OF SUBULURA (NEMATODA: SUBULUROIDEA) FROM GROUND SQUIRRELS, SPERMOPHILUS SPILOSOMA BENNETT, 1833, IN NEW MEXICO
}

\author{
John E. Ubelaker, Roxanne Easter-Taylor, April Marshall, and Donald W. Duszynski ${ }^{\star}$ \\ Department of Biological Sciences, Southern Methodist University, Dallas, Texas 75205. e-mail: ubelaker@smu.edu
}

\begin{abstract}
A description is presented of a new species of Subulura Molin, 1860, Subulura novomexicanus, collected from the spotted ground squirrel, Spermophilus spilosoma Bennett, 1833, in New Mexico. The males are 24 to $29 \mathrm{~mm}$ long, precloacal sucker 1.7-2.0 mm from posterior end, spicules subequal 0.83-1.0 long, and gubernaculum Y-shaped 0.21-0.39 mm long. Females are 34-39 mm long, vulva near middle of body $14.06-22.00 \mathrm{~mm}$ from anterior end, and eggs $0.04-0.05 \mathrm{~mm}$ long by $0.03-0.04$ $\mathrm{mm}$ wide. The new species is distinguished from Subulura ungulatus Erickson, 1938 in being longer and having spicules that are distinctively different in size and form. It also differs from Subulura nevadense Babero, 1973 in being longer and having a larger egg size and smaller spicules. The new species is most similar to Subulura andersoni (Cobbold, 1876) (Thwaite, 1927); however, the males of this species are smaller and they have broad cervical alae, and the adults occur in squirrels of India. Reexamination of $S$. ungulatus showed 11 pairs of caudal papillae, including 4 pairs of preanals, 1 pair adanal and lateral, and 6 pairs of postanal papillae located at the end of the tail. Spermophilus richardsoni (Sabine, 1822) is a new host record for $S$. nevadense, and Montana is a new distributional record for this nematode. Eimeria callospermophili Henry, 1932, is a new record for S. spilosoma.
\end{abstract}

Here, we describe a new species of Subulura Molin, 1860. It was discovered in spotted ground squirrels, Spermophilus spilostoma Bennett, 1833, collected on the Sevilleta National Wildlife Refuge, near Sorocco, New Mexico. The only other mention of parasites from this species of ground squirrel is by Broda and Schmidt (1978), who reported the presence of $\mathrm{Hy}$ menolepis citelli McLeod, 1933, Citellina triradiata (Hall, 1916) Morgan, 1930, redescribed by Broda and Schmidt (1978), Physaloptera massino Schulz, 1926, and Trichuris sp. from Colorado. This is the first report of a species of Subulura from S. spilostoma.

\section{MATERIALS AND METHODS}

In total, 89 spotted ground squirrels were collected as part of The University of New Mexico's Long-Term Ecological Research (LTER) project on the Sevilleta National Wildlife Refuge, Sorocco Co., New Mexico, between 1990 and 1996. Two host specimens contained an undescribed species of Subulura that we describe here as a new species. A description of the site and host collection techniques on the LTER was published in Decker et al. (2001).

The parasites were removed from the alimentary tract of their hosts. They were fixed in 5\% buffered formalin and later transferred to $70 \%$ ethanol. Before examination, worms were cleared in ascending series of glycerin or heated lactophenol. Figures were made with the aid of a drawing tube. Measurements were from 6 male and 3 female worms, and they are given in millimeters $(\mathrm{mm})$. Holotype and paratypes are deposited in the U.S. National Parasite Collection (USNPC), Biosystematics and National Parasite Collection Unit, USDA, Agricultural Research Service, Beltsville, Maryland.

Symbiotype hosts were deposited in the Museum of Southwestern Biology Division of Mammals, at the University of New Mexico, Albuquerque, New Mexico. The squirrels were trapped (University of New Mexico Animal Care Use Permit 9410-B) at the sites during spring and summer (May-August) 1991-1994 using Sherman live-traps (models XLF15 and SFAL; H. B. Sherman Traps, Tallahassee, Florida) baited with rolled oats (Wilson et al., 1997).

\section{DESCRIPTION}

\section{Subulura novomexicanus $\mathrm{n}$. sp.}

(Figs. 1-5)

Description (based on 9 specimens): With the characteristics of the genus. Whitish nematodes tapering to both extremities, anterior end

Received 26 April 2006; revised 16 April 2007; accepted 16 April 2007.

* Department of Biology, The University of New Mexico, Albuquerque, New Mexico 87131-1091. with rounded cephalic tips. Cephalic plate with 4 ovoid and striated papillae, 2 prominent submedian amphids, and a hexagonal mouth opening surrounded by 6 smaller papillae. Mouth surrounded by 6 labial lobes, separated by 6 interlabia, characteristic of the subgenus, Murisubulura Quentin, 1969. Pharynx of 3 muscular portions, each composed of 3 lobes twisted to make the pharynx have a helicoidal structure. Two narrow lateral alae originate behind cephalic plate and terminate in region of the junction of muscular and glandular parts of esophagus; numerous and varied transversal striations present throughout alae. Esophagus dilated posteriorly with short neck followed by bulb.

Male $(n=6)$ : $24-29$ long by $0.49-0.59$ wide. Buccal cavity $0.05-$ 0.06 long by $0.04-0.048$ wide. Nerve ring and excretory canal $0.11-$ 0.12 and $0.34-0.35$ from anterior end, respectively; precloacal sucker located 1.7-2.0 from posterior end. Tail with terminal spine. Eleven pairs of ventral caudal papillae with 4 pairs of preanals that begin at the level of the precloacal sucker, 1 pair adanal and lateral, and 6 pairs of postanal, 4 near the end of the tail. Anus to tip of tail, including terminal spine $0.24-0.38$. Spicules alated, equal to subequal, $0.83-1.0$ long, gubernaculum Y-shaped 0.21-0.39 long.

Female $(n=3)$ : $34-39$ long by $0.5-0.8$ wide. Buccal cavity 0.04 0.07 long by $0.03-0.7$ wide. Esophagus length with bulb $1.8-2.1$ long. Nerve ring $0.41-0.43$ and excretory pore $0.62-0.66$ from anterior end. Vulva near middle of body, 14.06-22.58 from anterior end. Eggs 0.04$0.05 \mathrm{~mm}$ long by $0.03-0.04$ wide. Tail $1.58-1.59$ long.

\section{Taxonomic summary}

Type host: Spermophilus spilosoma Bennett, 1833.

Site of infection: Caecum and large intestine.

Type locality: Sevilleta National Wildlife Refuge, Socorro Co., New Mexico.

Specimens deposited: Holotype male and allotype female and paratypes, USNPC 099587.00, 099588.00, and 099589.00, respectively. Symbiotype hosts: MSB 19049 captured in 1989 and MSB 26856 captured in 1993, both from Five Points Grassland.

Etymology: The specific name of this species refers to the state of New Mexico, where the specimens were collected.

\section{DISCUSSION}

The genus Subulura contains many species occurring in both birds and mammals. Two species of Subulura are known to occur in rodents in North America. Subulura ungulatus Erickson, 1938, from Zapus hudsonius (Zimmermann, 1780), collected in Minnesota, is a much smaller nematode (males 15-16 $\mathrm{mm}$ long vs. $24-29 \mathrm{~mm}$ ), with males having spicules similar in length to our new species. Erickson (1938) did not record all the caudal papillae present in the male specimens. Examination of the type specimen revealed that there are 11 pairs of caudal 


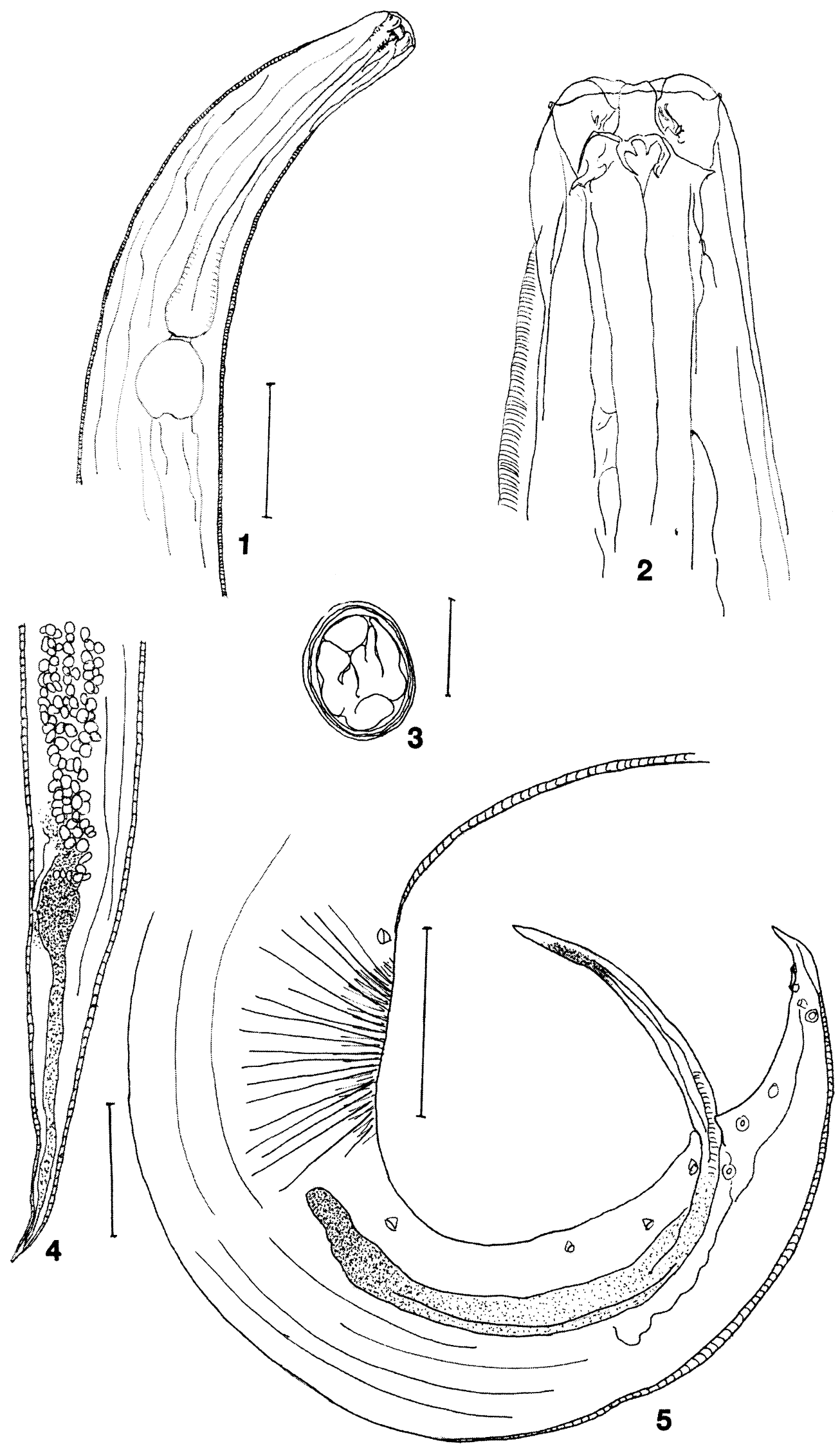

Figures 1-5. Subulura novomexicanus n. sp., parasite of Spermophilus spilosoma from New Mexico. (1) Anterior end of male showing esophagus and bulb. Bar $=300 \mu \mathrm{m}$. (2) Anterior end of male with detail of buccal capsule and lateral alae. Bar $=400 \mu \mathrm{m}$. (3) Egg. Bar $=200$ $\mu \mathrm{m}$. (4) Posterior end of female. Bar $=300 \mu \mathrm{m}$. (5) Posterior region of male showing ventral sucker (vs) and spicules (s). Bar $=400 \mu \mathrm{m}$. 
papillae, including 4 pairs of preanals, 1 pair adanal and lateral, and 6 pairs of postanal papillae, including 4 small papillae located at the tip of the tail. Thus, $S$. ungulatus is similar to most species of Subulura from rodents in the distribution of caudal papillae, including the new species described here.

A second species, Subulura nevadense Babero, 1973, occurs in Spermophilus tereticaudus Baird, 1858 and Ammospermophilus leucurus (Merriam, 1893), from Clark, Lincoln and Nye counties, Nevada (Babero, 1973). The males of S. nevadense are significantly shorter (9.9-13) than our new species. In addition, in males of $S$. nevadense, the anterior most caudal papillae are located much anterior to the adanal sucker, and in the females, the egg size is larger (0.08-0.09) than our new species (0.04-0.05). We also examined Subulura specimens deposited in the USNPC (042484.00, 042485.00, and 042490.00) collected from Spermophilus richardsoni (Sabine, 1822) in Beaverhead, Montana, by Jellison in 1936 and deposited in the USNM Helminthological Collections. These specimens are all similar to $S$. nevadense; thus, $S$. richardsoni represents a new host record, and Montana is a new distributional record for this parasite. In all specimens of $S$. nevadense examined, the males from $S$. richardsoni were within the range reported by Babero (1973) and shorter than those of the new species we report here.

The new species is also morphologically similar to $S$. andersoni as redescribed by Thwaite, 1927, as presented by Baylis (1936). In S. andersoni, the males are smaller (13.5-14.9) than $S$. novomexicanus, have broad cervical alae, and the adults are only known to occur in squirrels of India.

In our study, a single host animal (both males) collected in spring 1989 contained 5 male and 1 female $S$. novomexicanus, a juvenile Physaloptera massino, and Eimeria callospermophili Henry, 1932; and a second animal captured 4 yr later in spring 1993 contained 1 male and 2 female $S$. novomexicanus, a single Hymenolepis sp. 1 male and 3 females of Heligmosoides sp., 4 females of $P$. massino, and a female of $C$. triradiata, and $E$. callospermophili. Both ground squirrels occurred in a grassland habitat described by Decker et al. (2001). Broda and Schmidt (1978) surveyed the parasites of this squirrel species, and they did not find Subulura species in the 38 animals examined from northern Colorado. They did record the presence of Eimeria larimerensis, Hymenolepis citelli, Citellina triradiata, Physaloptera massino, and Trichuris sp. in this host. The report here of E. callospermophili is a new host record for this ground squirrel.

\section{ACKNOWLEDGMENTS}

We thank J. Ralph Lichtenfels and Eric P. Hoberg for access to archived specimens and for depositing specimens in the National Parasite Collection at Beltsville, Maryland. This project was supported by the UNM Sevilleta LTER program (NSF BSR-88-11906; DEB 95-9411976) and by a Survey and Inventory grant (NSF DEB-95-05025) to D.W.D. This is publication number 390 of the Sevilleta National Wildlife Refuge Long-Term Ecological Research project.

\section{LITERATURE CITED}

BAYLIS, H. A. 1936. The fauna of British India. Nematoda. Ascaroidea and Strongyloidea. Taylor and Francis, London, U.K., 408 p.

BABERO, B. B. 1973. Nematodes of Nevada ground squirrels, with description of two new species. Transactions of the American Microscopical Society 92: 265-272.

BrodA, R. J., AND G. D. SChMidT. 1978. Endoparasites of the spotted ground squirrel, Spermophilus spilosoma Bennett, 1833, from Colorado. Journal of Helminthology 52: 323-326.

Decker, K. H., D. W. Duszynski, And M. J. PAtrick. 2001. Biotic and abiotic effects on endoparasites infecting Dipodomys and Perognathus species. Journal of Parasitology 87: 300-307.

ERICKSON, A. B. 1938. Parasites of some Minnesota Cricetidae and Zapoidae, and a host catalogue of helminth parasites of native American mice. American Midland Naturalist 20: 575-589.

Thwaite, J. W. 1927. On a collection of nematodes from Ceylon. Annals of Tropical Medicine and Parasitology 21: 225-244.

Willson, W. D., J. A. HnidA, AND D. W. Duszynski. 1997. Parasites of mammals on the Sevilleta National Wildlife Refuge, Socorro, New Mexico: Cuterebra austeni and C. neomexicana (Diptera: Oestridae) from Neotoma and Peromyscus (Rodentia: Muridae), 19911994. Journal of Medical Entomology 34: 361-367. 